\title{
Gender Equality, Pro-Poor Growth and Mdg Goal 1 In South African Municipal Governance: The Case of Sedibeng District Municipality
}

\author{
Prof. Shikha Vyas-Doorgapersad
}

\author{
North-West University, Vanderbijpark, South Africa
}

Email: Shikha.VyasDoorgapersad@nwu.ac.za

Doi:10.5901/mjss.2014.v5n21p327

\begin{abstract}
The Republic of South Africa has introduced transformation processes through relevant legislative and statutory frameworks to ensure that the country is administered in a non-sexist manner. The aspect of gender equality is a vital element in the South African Constitution that now links the government's manifesto to the objectives of the Millennium Development Goals (MDGs). Under this imprint, South African municipal governance is constantly looking for new approaches for solving socio-economic issues such as combating poverty and enhancing sustainable development. Gender equality, pro-poor growth strategies and the MDG goal 1 are important focus areas in the discourse on extreme poverty reduction. The aim of this article is to explore the links between gender equality, pro-poor growth strategies and MDG goal 1. The case study of a specific municipality (Sedibeng District Municipality [SDM]) is explored, providing a detailed analysis of its gender equality measures and pro-poor strategies. In order to rationalize the status quo, a questionnaire was distributed to residents of SDM and interviews were conducted with personnel of SDM. Based on these findings, the article offers relevant recommendations for improvement. The relationship between gender and poverty is a complex topic that is now being debated more urgently than ever before. We know that poverty is linked to gender but this article aims to explore and rationalize these links. Given the magnitude of poverty challenges, the article concludes with proposing a municipal assessment tool to identify the gaps in municipal capabilities for implementing gender-based pro-poor strategies at institutional level.
\end{abstract}

Keywords: gender, gender equality, pro-poor growth, municipality, Millennium Development Goals.

\section{Introduction}

The tem gender is defined conceptually by various scholars (Moore, 1994; Thomas, 1995; Goodman, 1996; Tischler, 1996; Bornstein, 1998; Evans, 2000; Reeves \& Baden, 2003; Waiten, 2004; Wharton, 2005; Scott \& Marshall, 2005; Giddens, 2009; Connell, 2009) as behavioural and attitudinal differences of feminism and masculine aspects of varied personalities. Gender does not only refer to biological sex but also encompasses the roles, responsibilities, attributes, attitudes and factors that differentiate males and females; it also looks at what it means to be male or female and how they relate to each other.

Gender equality is defined by researchers, scholars, and international organizations (Reeves \& Baden, 2000; Grown et al., 2003; United States Agency for International Development [USAID], 2008; Australian Development Cooperation, 2010; Office for the Co-ordination of Humanitarian Affairs [OCHA] Gender Toolkit, 2012) as the provision of equal opportunities and recognition to both men and women at the work place, and includes equality in job prospects and career enhancement. According to Mukhopadhyay (2004), there are two strategies in which gender inequalities can be mainstreamed:

- Integrationist strategies, which deal with the inclusion of gender equality concerns in the analysis, monitoring and evaluation of policies; and

- Transformative strategies, which involve placing women's interests in all development programmes and ensuring the development for change (p.6).

Gender equality means that being born male or female does not hinder the ambitions, aspirations and roles played by individuals. In other words both men and women are able to realize their full potential; they have equal chances for participation, success and benefiting from equal opportunities.

Pro-poor growth and pro-poor strategies are interventions that "have been put in place to enable poor men and women to participate in growth and development" (Organisation for Economic Co-operation and Development [OECD], 2006). Achieving the Millennium Development Goals will require rapid and substantial growth in developing countries. While most poverty reduction strategies do in fact acknowledge the importance of growth, many of them can be improved 
if a clearer analysis of the sources of growth is made and attention given to the interconnection between growth and poverty reduction. Developing a shared understanding of what we mean by pro-poor growth is vital for improving this analysis and for clarifying the dialogue taking place between policy-makers (Department for International Development [DFID], 2004). According to Klasen (2007), growth is therefore "pro-poor if it brings reduction in poverty", but he then goes on to caution that there are those who "see it as pro-poor only if it leads to disproportionate increase in the income of the poor, that is, if it is associated with a decline in inequality. Although the two definitions have merit, from the policy perspective it is crucial to define pro-poor growth as growth that minimizes the income gains of the poor and thus accelerates progress towards meeting MDG 1". Pro-poor strategies therefore are formulated to help in the reduction of poverty and to promote growth for the poor. Without effective pro-poor strategies and policies, "the human capacities of poor men and women may remain underdeveloped despite increased incomes" leading to a lack of development of human capacities among the poor, which in turn "reduces the rate of growth and the extent to which growth is pro-poor" (OECD, 2006), and results in countries failing to achieve the MDG goal 1.

\section{Link between Gender Equality, Pro-Poor Strategies and MDG 1: A Nexus}

The Millennium Development Goals (MDGs) are eight developmental goals created by the United Nations following the Millennium Summit in the year 2000. The development goals are to be achieved by the year 2015 and should promote sustainable human development and growth. The MDG goal 1 focuses on the eradication of extreme poverty and hunger. The eradication of poverty is dependent on the increase in employment rates amongst females. It is unacceptable that unemployment among women is very high. At global level, gender equality is a cross-cutting issue covering all dimensions of poverty. It is emphasized in the UN-MDG Report (2013) that the gender gap in employment is rising, "with a 24.8 percentage point difference between men and women in the employment-to-population ratio in 2012". The report goes on to explain that the "gap is most acute in Northern Africa ... where women are far less likely to be employed than their male counterparts". At the holistic level, this gender inequality may well "hamper the economic environment of [any] continent/region/country". The report maintains that "in sub-Saharan Africa, almost half the population live on less than $\$ 1.25$ a day. Sub-Saharan Africa is the only region that saw the number of people living in extreme poverty rise steadily, from 290 million in 1990 to 414 million in 2010". These poverty-stricken people in the region account for "more than a third of people worldwide who are destitute".

The MDGs require governments "to implement principles that are not discriminatory to women and the mainstreaming of gender is a principal strategy to fulfilling the obligation" (Painter, 2004). Strategies must ensure that "gender inequality prolongs the adversity of poverty on the lives of women and men. Gender equality ... can reduce the impact of poverty and help in improving pro-poor growth strategies" (Jones et al., 2008). In establishing the connection between gender equality, pro-poor strategies and MDG goal 1, Sumner and Melamed (2010) hold that MDGs are a set of indicators, a norm for poverty eradication and a structure for pro-poor development strategies. According to Manning (Sumner \& Melamed, 2010), the MDG goal 1 should be taken as a strategy to promote sustainable pro-poor strategies. This should include "the focus or attention to which poor women and men are able to participate in their economic matters, contribute to and benefit from growth" (OECD, 2006) for their sustainable social and economic development. There should be clarity on the exact meaning of poor; who is poor; and what clarifies the category or level of poor. This precision can be established through gender-disaggregated research and gender-based demographic data. The research should be enhanced by the compilation of a gender-based pro-poor/poverty database. This resourcefulness can then create an enabling environment whereby "women and men ... participate directly and equally as agents of change in the reduction of poverty" (OECD, 2009). In addition, the Organisation for Economic Co-operation and Development (2009) suggests that in order to achieve pro-poor growth strategies and meet MGD goal 1 timeously, the following should be considered:

- Increasing employability of poor people especially women will enable their abilities to contribute economically and to the achievement of MDG goal 1; and

- Social protection is important and it enables poor women and men to participate in poverty reduction initiatives to enhance the effectiveness of pro-poor strategies.

These actions can help to enable the pro-poor growth strategies in developing states. One fundamental principle of pro-poor growth strategies is that they focus on the development of poor people and limit the discrimination on the basis of gender. Pro-poor growth requires strategies that favour the poor so that they benefit from the strategies more than the rich (Kakwani \& Pernia, 2000). It should be noted that poverty reduction cannot happen effectively without reducing gender inequality. Furthermore, gender inequalities defeat the whole purpose of MDG goal 1.

The root causes of poverty and gender inequality are embedded in the ruling global macro-economic framework. 
There is a need "to analyze the intersecting effects of gender inequality with other factors that determine the achievement of MDGs, including the interconnectedness between the MDGs" (Division for the Advancement of Women [DAW], 2005). The MDGs must analyze the causes of the issues involved and not just identify the symptoms. Painter (2004) maintains that Goal 1 (the eradication of extreme poverty and hunger) only sees poverty in terms of "economic want and does not consider social and political marginalization, both of which are a result and a fundamental cause of poverty". It is argued that "if we apply this to the position of women, no consideration is given to why and how poverty affects women and men differently and how they experience poverty differently". Poverty is a gender-based issue because it has different impacts on women and men, boys and girls and it should therefore be viewed as a gendered experience.

\section{Gender Equality and Pro-Poor Strategies in South African Municipal Governance}

The concern is: "to what extent does local government support women's empowerment and gender equity?" (Todes et al., 2007). Researchers (Mathye, 2002; Tsuari, 2010; Penceliah, 2011; Sithole et al., 2012) have explored this issue and emphasize that the municipal outputs are not gender-specific. There are still some municipalities that do not invest in offering training programmes for gender analysis; and furthermore, professional roles are not extended to women. As Parker (2009) puts it, "One can immediately deduce that gender equality policies are not correctly implemented and that women are not empowered to acquire the requisite skills to hold management positions. It merely shows that the inclusion of women in local government is a matter of policy". South Africa's experience of democratic reform has demonstrated that local government poses immense and particular challenges for advancing gender (Govender \& Doorgapersad, 2013). Before 1994, women in South Africa were not provided with opportunities equal to those of their male counterparts. For the most part they were unable to express their managerial abilities and expertise, particularly in public service management positions (Mello \& Phago, 2007).

The post-1994 democratic dispensation, followed by a three-tiered, decentralized system of governance, has meant that municipal governance is responsible for meeting the needs of local communities. Communication channels between the government and governed have been improved; and there are opportunities for citizen participation (including women) in the affairs of municipal governance. This has certainly increased women's representation in politics (Beall, 2004).The research undertaken by the Human Sciences Research Council (HSRC), cited by Bruns (2007) reveals that "gender is [still] seen as a marginal issue within most municipalities, and that women's voices struggle to be heard". While there is a certain degree of female representation in some municipalities, these women feel constrained from taking up gender issues within existing structures. (Govender \& Doorgapersad, 2013).

There are eight metropolitan municipalities, 44 district municipalities and 226 local municipalities in South Africa. The municipalities are regulated by the Constitution of the Republic of South Africa (1996); the White Paper on Local Government (1998); the Municipal Systems Act, No. 32 of 2000; and the Municipal Structures Act, No. 117 of 1998. This article explores the status quo of South African municipal governance in response to the allegations of gender inequality in pro-poor strategies. To bring this area into discussion, one specific municipality (Sedibeng District Municipality) is considered as a case study to analyze the situation in detail. The study is ongoing and will investigate comparative studies in future publications.

\subsection{Status quo in Sedibeng District Municipality}

\subsubsection{Demographics}

The Sedibeng District Municipality (SDM) is a Category C municipality found in the Gauteng Province. It is situated on the banks of Vaal River and Vaal Dam in the southern-most part of Gauteng, covering the area previously known as the Vaal Triangle. It includes the towns of Vereeniging, Vanderbijpark, Meyerton and Heidelberg as well as the historic townships of Sharpeville, Evaton, Sebokeng, Bophelong, and Ratanda, which have a rich political history and heritage. The SDM covers the entire southern area of Gauteng Province, extending along a $120 \mathrm{~km}$ axis from east to west. The total geographic area of the municipality is 3894 square kilometres. The SDM comprises three Category B (local) municipalities, namely Emfuleni, Lesedi and Midvaal Local Municipalities and is surrounded by the following municipalities: City of Johannesburg (Johannesburg) to the north; Ekurhuleni (East Rand) to the northeast; Nkangala (in the Mpumalanga Province) to the northeast; Gert Sibande (Mpumalanga Province) to the east; Northern Free State (Free

State Province) to the south; Southern District (North-West Province) to the west; and West Rand to the northwest (SDM Integrated Development Plan, 2009). According to the Development Bank of Southern Africa (DBSA) (2007) projections, which are based on the Statistics SA Census 2001 population figures, the total population of Sedibeng District 
Municipality is 908107 (SDM Annual Report, 2009).

\subsubsection{Gender and unemployment levels in SDM community}

There was a decline in the total number of economically active people in the SDM from 339296 in 2009, to 325763 in 2010. This represents 13633 jobs lost. Of the economically active population $54.8 \%$ were males, while $45.2 \%$ were females (SDM IDP, 2011/2012). In terms of gender, "Black females recorded the highest unemployment figures in the District [SDM] at 95.84\%" (SDM IDP, 2011/2012).

\subsubsection{Gender equality and MDG in SDM office}

The Sedibeng District Municipality faces a serious challenge in its efforts to implement gender equality policies in accordance with the requirements of the millennium development goal. The demographics for 2005/2006 indicate that "SDM is not complying with the required legislation resulting in fewer women occupying managerial positions than men" (SDM Report 2005/2006). In fact 83\% of those holding senior and top management positions were men as opposed to females (17\%). Furthermore, technical and professional positions were largely occupied by males (67\%) in comparison to females (33\%)

The 2007/2008 SDM Annual Report revealed "clear discrepancies between men and women in its employment structure". The report showed that of the 756 employees (total number), 392 were males and 364 were females. Of the 16 positions designated as top management posts, only three (19\%) were held by women, while $13(81 \%)$ were occupied by men. At senior management level, out of 48 positions, females occupied only $12(25 \%)$, while males once again dominated with $36(75 \%)$. The percentage of males in top and senior management positions was therefore $76.5 \%$, compared to a $23.5 \%$ of females. From this it can be concluded that women were by and large considered for positions of lower authority, such as junior management positions and non-permanent posts, which called for relatively less decision making and were thus accorded lower status and lower grading.

In its 2009/2010 Annual Report, the SDM revealed the following demographics: Top management, $81.6 \%$ (males) and 18.6\% (females); senior management, 64\% (males) and 36\% (females); professionally qualified and middle management, $56 \%$ (males) and 44\% (females); in "skilled, junior management and supervisory positions", $52 \%$ (males) and $48 \%$ (females). However, in this 2009/2010 Annual Report, SDM committed itself to the development of a Employment Equity Policy and Plan to address these discrepancies.

In its report (2010/2011), SDM reported on its equity statistics, showing that men occupied $83 \%$ of top management positions while females occupied only $16 \%$. In the senior management positions category, $70 \%$ are occupied by males and $30 \%$ by females. The percentage of males in top and senior management positions is $76.5 \%$ while females only hols $23.5 \%$ of these posts. Similarly, women occupy $53 \%$ of junior and supervisory positions and $68 \%$ of semi-skilled workers' jobs while men hold $58 \%$ and $47 \%$ respectively in these two categories. The equity statistics appear to be unsatisfactory for the 2012/2013 financial years.

Once again it is still quite evident that although the total number of males and females employed in SDM are almost on par, the type of positions that females occupy are questionable. Female employees are still not used widely in the top or senior management positions and are still under-represented in top management and senior management positions.

\subsection{Gender and Pro-poor growth in SDM: Empirical findings}

The SDM has been identified as a municipal district where three main economic sectors, namely tourism, agriculture and manufacturing are concentrated within its borders. Apart from being an economic hub, these municipalities (Emfuleni, Midvaal and Lesedi) have a large concentration of industries and as a result, they have become the main manufacturing centre of South Africa (Statistics South Africa, 2001). However, the current economic activity is no longer sufficient to sustain the area, and diversification is now imperative if the economy of SDM is to grow (Sedibeng District Municipality, 2009/2010).

This leads to SDM being characterized by: high unemployment, declining local economy and poor growth prospects in the short term (Sedibeng District Municipality, 2009/2010). The situation is complicated by the fact that "the implementation of pro-poor strategies ... at Sedibeng District Municipality is poorly executed. Additionally there is no overarching economic development strategy to underpin them. Where sub-strategies have been developed, these are generally characterised by poor implementation" (SDM, 2009/2010). More specifically these plans show little co- 
ordination across initiatives, no prioritization of initiatives, inadequate attention to resourcing; and minimal input by stakeholders (Kabemba, 2003; also refer Swanepoel \& De Beer, 2006; and Buccus, 2007); limited external and internal communication; and no attention to the organisational implications of economic development initiatives (SDM, 2009/2010).

In order to find out whether pro-poor strategies incorporate gender equality at SDM, a pilot study was conducted in 2012. ${ }^{1}$ The Human Resource director (Mr Cliff Ramotsedisi), acknowledged in a personal interview (06 August 2012), that the "current gender equality implementation is off the mark due to barriers experienced" (Ramotsedisi, 2012). He emphasized that he believes "women are not sufficiently represented at the Sedibeng District Municipality in high positions". The Skills Development officer (Mr Mokhele Kolokotho) confirmed this statement, stressing that "women do attend training programmes, but not in the areas of top and senior management" (personal interview, 06 August 2012). In order to obtain the opinions and perceptions of community members in SDM, a structured questionnaire was prepared. Following the simple random approach, the questionnaire was distributed as follows (refer to Table 1):

Table 1: Demography of responses

\begin{tabular}{|c|c|c|c|}
\hline \multicolumn{3}{|c|}{ Sedibeng District Municipality } \\
\hline & Emfuleni Local Municipality & Midvaal Local Municipality & Lasedi Local Municipality \\
\hline Male & 40 & 40 & 40 \\
\hline Female & 40 & 40 & 40 \\
\hline Total =240 & 80 & 80 & 80 \\
\hline
\end{tabular}

The respondents varied in age between 25 and 60 years, are all employed, and were thus able to provide significant feedback on the focus of this study. An equal number of males and females were considered for gender-disaggregated responses. The responses nonetheless are combined for an unbiased/objective outcome as follows (refer to Table 2):

Table 2: Themes and responses

\begin{tabular}{|c|c|c|c|}
\hline Themes & Yes & No & Total responses \\
\hline Women in the family earn more than men & 78 & 182 & $100 \%$ \\
\hline Women are allowed to take financial decisions in the home & 191 & 49 & $100 \%$ \\
\hline Men feel threatened with women gaining dominance in the professional field & 74 & 166 & $100 \%$ \\
\hline Personally promote women to participate in socio-economic development & 194 & 66 & $100 \%$ \\
\hline Aware of pro-poor strategies in the municipality & 160 & 86 & $100 \%$ \\
\hline Support that gender-based employment opportunities must be implemented in the municipality & 203 & 37 & $100 \%$ \\
\hline $\begin{array}{l}\text { Support that gender-based distribution of work can promote socio-economic development in the } \\
\text { municipality }\end{array}$ & 202 & 38 & $100 \%$ \\
\hline Support that gender-based pro-poor strategies are vital for poverty reduction in the municipality & 192 & 48 & $100 \%$ \\
\hline Gender-based recognition of work can promote socio-economic development in the municipality & 199 & 41 & $100 \%$ \\
\hline Propose that the municipality must promote gender-based research for socio-economic development & 200 & 40 & $100 \%$ \\
\hline Propose gender equality for socio-economic development in the municipality & 214 & 26 & $100 \%$ \\
\hline Propose gender equality in pro-poor strategies for poverty reduction in the municipality & 225 & 28 & $100 \%$ \\
\hline
\end{tabular}

The responses reveal a positive scenario; community members are willing to promote a gender-based approach in socioeconomic development. This also investigates the fact that males are becoming more accepting of female empowerment at both personal and professional fronts.

The responses of community members do not correspond with the vision of the Sedibeng District Municipality. The MEC (member of the Executive Council) raised concerns when commenting on the IDP for 2008/2009. He highlighted that a "lack of an Employment Equity Plan (EEP) inhibits the SDM's ability to address gender equality. The SDM is advised to develop the EEP in order to fill critical vacancies in the municipality and address institutional transformation and women empowerment to build the municipality into a sound institution premised on excellence". The MEC's statement underlines the viewpoint provided in the Sedibeng District Municipality's Integrated Development Plan (2010)

${ }^{1}$ For a complete description of the pilot study, refer to Govender, S.D. and Vyas-Doorgapersad, S. (2013). The implementation of gender equality policies in achieving millennium development goal three in the Sedibeng District Municipality. Journal of Public Administration. 8 (1): 105-117. 
which maintains that "there is a lack of women representation in senior managers' positions".

The same nature of concern was again raised during the preparation of 2014/15 IDP Draft document in which the MEC stated that "although municipalities in Gauteng have made strides their attempts to integrate [gender] ${ }^{2}$ issues in their planning, serious challenges remain. The general picture with regard to the mainstreaming of [gender] issues in IDP's still shows gaps especially in relation to employment equity ... Efforts should also be intensified to prioritize [gender] in areas of Service Delivery, Employment Equity as well as Economic Empowerment" (SDM IDP, 2014/15).

\section{The Way Forward}

This quantitative study has identified gaps in municipal capability to implement gender equality in pro-poor strategies. These gaps are particularly evident in institutional capability related to human resources. Socio-economic developmental needs at municipal level must be identified, reviewed, prioritized and strategized by means of a Gender-Sensitive Municipal Assessment Tool (GS-MAT32), as discussed in the proposed model (refer to Figure 1).

At Sedibeng District Municipality, there is an ineffective implementation ${ }^{4}$ of gender equality in Employment Equity Plans; gender-based pro-poor strategies, gender-based quality of work life; and gender-based job satisfaction. At institutional level, the GS-MAT assesses the organizational structures and development plans, emphasizing "what do we deliver?" These concerns require close consideration, asking questions such as: Are the community needs covered by municipal development plans? This assessment assists the strategic policy-makers and decision-makers to identify the gender-based challenges in the implementation of pro-poor strategies. The GS-MAT then measures the impact (positive/negative) by identifying the gaps in delegated tasks ${ }^{5}$. A gap is an impediment within the municipal structure to implement service delivery mechanisms.

At institutional level, the gap analysis indicates that the entrepreneurial skills women possess lack institutional support and this has the highest score of 270 points. This is followed by financial independence with 252 points; the formal employment of women with 232 points; and social welfare with 224 points. Data obtained from a needs analysis/social impact assessment (at community level), and capability analysis (at municipal level) need to be identified, analysed, interpreted and reported for continuous improvement in the system.

\section{Conclusion}

This article concludes that gender is a fluid concept that changes constantly depending on the context in which it is explored. The definitions stated indicate that sex refers to a biological act, while gender is socially and culturally constructed over time. Nonetheless, all definitions and concepts concur that gender is the way society categorizes men and women in terms of behaviour, ambition and responsibilities. Through use of a literature review, citing the opinions of various academics and scholars, the article deduces that MDGs are interlinked. However, gender is only explicitly mentioned in MDGs 3 and 5. This inclusion in only two of the MDGs is far too narrow. Other MDGs make no mention at all of gender-specific risks and allied vulnerabilities. They exclude important issues such as gender-specific roles, responsibilities and power relations and are thus not geared to the promotion of gender equality, particularly as far as the empowerment of women and girls is concerned. Nor do they address the development challenges that must be met if sustainable poverty reduction is to be achieved. The objective of MDG goal 1 is to reduce the number of people living in poverty and hunger. By offering gender-based employment opportunities to men and women, economic/pro-poor growth can be sustained. This requires that municipalities give serious consideration to establishing gender-based and gendersensitive in their strategic development plans; increase women's participation in local decision-making through political party quotas; and address the issue of employment equity targets. Pro-poor strategies need to be filtered into strategic development plans and municipal policies must target poverty alleviation and the empowerment of women.

\footnotetext{
${ }^{2}$ The author has replaced and restricted the original concept of Gender, Youth and People with Disabilities (GEYODI) to maintain the focus of the article specifically on gender.

${ }^{3}$ The author initially developed a Municipal Assessment Tool [MAT]. This tool can be utilized with diverse variables assessing varied aspects of municipal capabilities and gaps in different scenarios. In this article, the MAT is linked with gender-based aspects of the municipality.

${ }^{4}$ The questions raised in the questionnaire are categorized into four main themes in the GS-MAT, viz. gender equality in Employment Equity Plans; gender-based pro-poor strategies, gender-based quality of work life, and gender-based job satisfaction.

${ }^{5}$ The Gs-MAT tool indicates weighting that is the level of urgency by the community (highest: 10; lowest 0). * The weightings stated in the model and explanation, are hypothetical. This proposed model suggests that weighting can differ based on the municipal community survey, performed at any given time and place.
} 
Epilogue: The National Assembly of the South African government has given holistic approval to the Women and Gender Equality Bill (Gazette No. 37005 of 6 November 2013), and this may well have a positive impact on the realization of gender mainstreaming in MDG goal 1. The implementation and impact of the Bill will be researched and reviewed in the coming years.

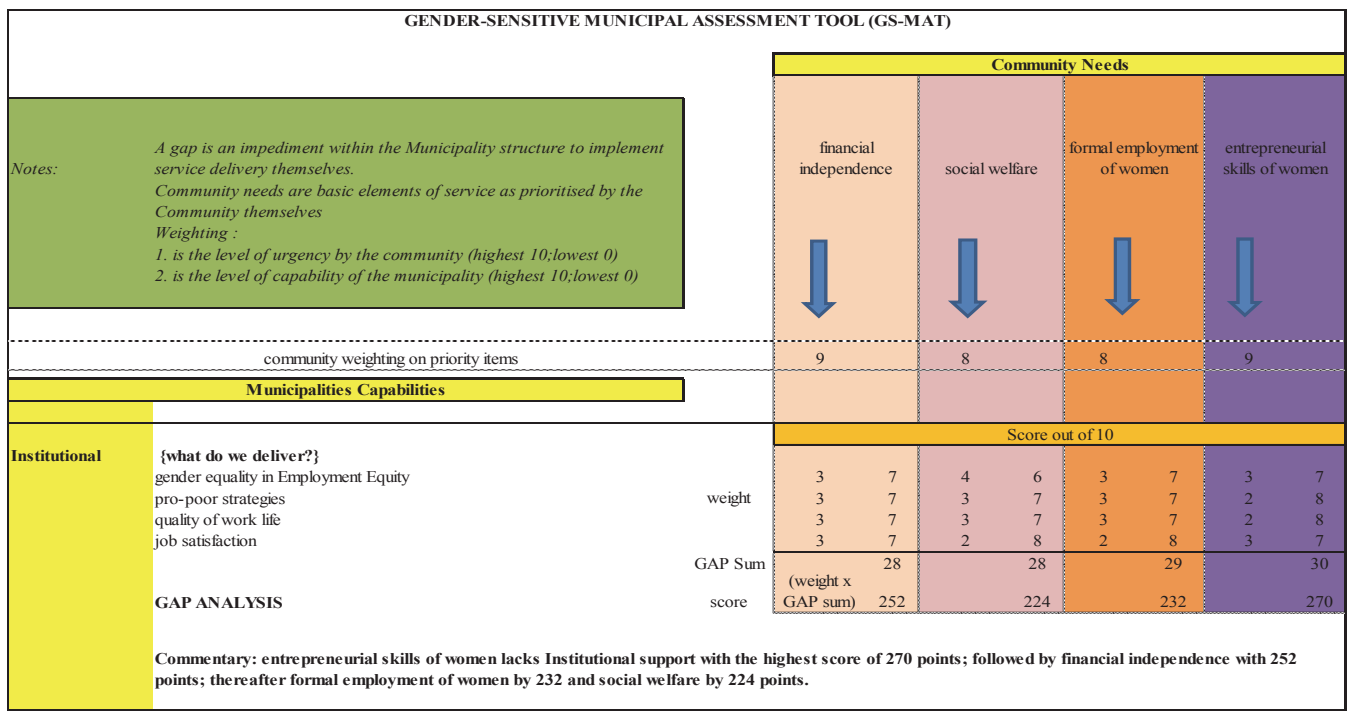

Figure 1: Gender-Sensitive Municipal Assessment Tool (GS-MAT)

\section{References}

Australian Development Co-operation. (2010). Gender equality and empowerment of women. Policy document. http://www.entwicklung. at/uploads/media/PD_Gender_Equality_19032010_Web.pdf

Beall, J. (2004). Decentralisation and Engendering Democracy: Lessons from local government reform in South Africa. London: Development Destin Studies Institute.

Bornstein, K. (1998). My Gender Workbook. New York: Routledge.

Bruns, K. (2007). Local government, gender and integrated development planning. Pretoria: HSRC.

Buccus, I. (2007). Public Participation and Local Governance. University of Kwazulu Natal: The Centre for Public Participation.

Connell, R. (2009). Short Introductions - Gender. Boston, USA: Polity Press.

Division for the Advancement of Women (DAW). (2005). Achievements, gaps and challenges in linking the implementation of the Beijing platform for Action and the Millennium Declaration and Millennium Development Goals. Report of the expert group meeting. New York: United Nations. http://www.un.org/womenwatch/daw.

Department for International Development (DFID). (2004). Pro-poor Growth Briefing Note 1. February 2004. London: DFID.

Evans, L. (2000). Considering gender. Salut, 7(6), June 2000.

Giddens, A. (2009). Sociology. Cambridge, UK: Polity Press.

Goodman, L. (1996). Approaching literature - Approaching literature and gender. New York: Routledge.

Govender, S.D. and Vyas-Doorgapersad, S. (2013). The implementation of gender equality policies in achieving millennium development goal three in the Sedibeng District Municipality. Journal of Public Administration. 8 (1), 105-117.

Grown, C., Gupta, G.R. \& Khan, Z. (2003). Promises to keep: achieving gender equality and the empowerment of women. www. princetown.edu

Grown, C., Gupta, G.R. \& Khan, Z. (2003). A Background Paper for the Task Force on Education and Gender Equality of the Millennium Project. Washington. D.C.: International Centre on Women.

Jones, N., Holmes, R. \& Espey, J. (2008). Gender and the MDGs. ODI Briefing Paper 42. London: ODI.

Kakwani, N. and Pernia, E.M. (2000). Asian Development Bank. Asian Development Review.8 (1), 1-16.

Kabemba, C. (2003). The impact of democracy on public participation in the SADC region: realizing effective and sustainable democratic governance in South Africa and beyond. University of Kwazulu Natal: Centre for Public Participation.

Klasen, S. (2007). Detriments of pro-poor growth. www.ifpri.org/sites/default/files/publications/oc63ch13.pdf

Mathye, M. (2002). Integrated Development Planning: a gender perspective. Braamfontein: Commission on Gender Equality.

Mello, D.M. \& Phago, K.P. (2007). Affirming women in managerial positions in the South African Public Service. Pretoria: Unisa Press. 
Moore, H. (1994). A passion for difference: essays and anthropology and gender. Bloomington, IN: Indiana University Press.

Mukhopadhyay, M. (2004). Mainstreaming gender or "streaming" gender away: feminists marooned in the development business. IDS Bulletin. 35(4), 95-103.

Office for the Co-ordination of Humanitarian Affairs [OCHA] Gender Toolkit. (2012). Gender definitions and mandates. https://docs. unocha.org/sites/dms/Documents/GenderToolkit1_121205_5_ver7.pdf..

Organisation for Economic Co-operation and Development (OECD). (2006). Promoting pro-poor Growth: Key policy messages. Paris: OECD.

OECD. (2009). Promoting pro-poor growth social protection. Paris: OECD.

OECD. (2010). Gender Equality and the MDGs: what is missing? Paris: OECD.

Painter, G.R. (2004). Gender, the Millennium Development Goals, human rights in context of 2005 review processes. www.choike.org/documentos/mdg_women2004.pdf.

Parker, F. (2009). Women still struggle for equality. Mail \& Guardian. 28 August 28 to 3 September 2009.

Penceliah, Y. (2011). Gender Mainstreaming with special reference to senior management in local government. Journal of Public Administration. 46 (1.1), 868-880.

Reeves, H. \& Baden, S. (2000). Gender and Development: concepts and definitions. Bridge (development gender)- Report no. 55. UK: DFIP.

Republic of South Africa. (1996). Constitution of the Republic of South Africa, 1996. Pretoria: Government Printer.

Republic of South Africa. (1998). Municipal Structures Act (Act 117 of 1998). Pretoria: Government Printer.

Republic of South Africa. (1998). White Paper on Local Government, 1998. Pretoria: Government Printer.

Republic of South Africa. (2000). Municipal Systems Act (Act 32 of 2000). Pretoria: Government Printer.

Republic of South Africa. (2001). Census 2001. Pretoria: Stats South Africa.

Sedibeng District Municipality. (2005). Annual Report. Vereeniging: SDM.

Sedibeng District Municipality. (2006). Annual Report. Vereeniging: SDM.

Sedibeng District Municipality. (2006). Integrated Development Plan. Vereeniging: SDM.

Sedibeng District Municipality. (2007). Annual Report. Vereeniging: SDM.

Sedibeng District Municipality. (2007). Integrated Development Plan. Vereeniging: SDM.

Sedibeng District Municipality. (2008). Annual Report. Vereeniging: SDM.

Sedibeng District Municipality. (2008). Integrated Development Plan. Vereeniging: SDM.

Sedibeng District Municipality. (2009). Annual Report. Vereeniging: SDM.

Sedibeng District Municipality. (2009). Integrated Development Plan. Vereeniging: SDM.

Sedibeng District Municipality. (2010). Annual Report. Vereeniging: SDM.

Sedibeng District Municipality. (2010). Integrated Development Plan. Vereeniging: SDM.

Sedibeng District Municipality. (2012). Annual Report. Vereeniging: SDM.

Sedibeng District Municipality. (2012). Personal Interview with Human Resource Director Vereeniging: SDM.

Sedibeng District Municipality. (2012). Personal Discussion with Skills Development Officer. Vereeniging: SDM.

Sedibeng District Municipality. (2014). Annual Report. Vereeniging: SDM.

Sedibeng District Municipality. (2014). Integrated Development Plan. Vereeniging: SDM.

Sithole, P. Todes, A. \& Williamson, A. (2012). Gender and women's participation in municipality-driven development: IDP and projectlevel participation in Msinga, eThekwini and Hibiscus Coast. http://www.cpp.org.za/publications/critical_dialoguel vol3no1_2007/chapter5.pdf.

Scott, J. \& Marshall, G. (2005). Oxford Dictionary of Sociology. NY: Oxford University Press.

Statistics South Africa. (2001). Policy context for Pro Poor Tourism in South Africa. Pretoria: Government Printer.

Sumner, A. and Melamed, C. (2010). Introduction - The MDGs and beyond: pro-poor policy in a changing world. IDS Bulletin.41 (1), 114.

Swanepoel, H. and De Beer, F. (2006). Community development: breaking the cycle of poverty. Pretoria: Juta.

Tischler, H.L. (1996). Introduction to sociology. Dumfries, NC, USA: Rinehart \& Winston, Inc.

Thomas, W.L. (1995). Sociology: the study of human relationships. Dumfries, NC, USA: Holt, Rinehart and Winston Inc.

Todes, A., Sithole, P. \& Williamson, A. (2007). Local Government, Gender and Integrated Development Planning. Pretoria: HSRC Press.

Tsauri, N.M. (2010). Implementation of Employment Equity for Gender Equality in the South African Police Service in Vereeniging. Unpublished mini-dissertation manuscript. North-West University: Vaal Triangle Campus.

United Nations. (2013). The Millennium Development Goals Report 2013. http://www.un.org/millenniumgoals/pdf/report-2013/mdgreport-2013-english.pdf

United States Agency for International Development (USAID). (2008). Gender Equality framework. New York: USAID.

Waiten, W. (2004). Psychology: themes of variations. Stamford, USA: Thomson Wadsworth.

Wharton, A.S. (2005). The sociology of gender - An introduction to theory and research. Hoboken, NJ, USA: Blackwell Publishing. 